\title{
Soviets admit improper committal to mental hospitals
}

London

Tru: Minister of Health of the Russian Soviet Federated Socialist Republic, A. Potapov, has admitted that some Soviet citizens have been improperly committed to mental hospitals on account of their outspokenness. In the past, the Soviet psychiatric establishment has consistently denied allegations that psychiatric methods were being applied against political dissidents.

This is still the official stance - and although it was recently reported that a

\section{Celltech undeterred by crash of ' 87 \\ London}

THE Slough-based biotechnology company Celltech is going ahead with plans for the biggest-ever private international share placing, despite the massive falls in the world's stock markets during the past three weeks. As a private company, Celltech is not directly affected by market fluctuations, and the company is confident that the $£ 50$-million placing will succeed.

Celltech was set up in 1980 with capital of $£ 12$ million from City institutions and the government. The company has grown steadily since - its approximate value was $£ 94$ million in August, before the 'readjustment' in company valuations — but as with other biotechnology companies, the profits are yet to come. In the year to September 1986, sales were $£ 11$ million for a loss of $£ 714,000$, but the company expects to make a profit this year.

Most of Celltech's income has come from monoclonal antibody production for diagnostic applications and, until now, products have been licensed at an early stage to major pharmaceutical companies for product development and clinical trials. The hoped-for $£ 50$ million is intended to enable the company to maintain European marketing rights in the most promising products resulting from in-house research, and to go on to the development and clinical-trial phase on its own behalf.

Perhaps to help the new share placing along, Celltech chose last week to announce a new contract from Ortho Pharmaceuticals which should bring in several million pounds over the next two years. Ortho recently won a licence from the US Food and Drug Administration to market the hormone erythropoietin for treating renal failure and to investigate its applicability in other diseases. Celltech's role will be to assist in the production of erythropoietin for the clinical trials and early marketing.

Charles Wenz law is being prepared making the political misuse of psychiatry a crime in the Soviet Union, some Soviet commentators have paradoxically presented the promised law

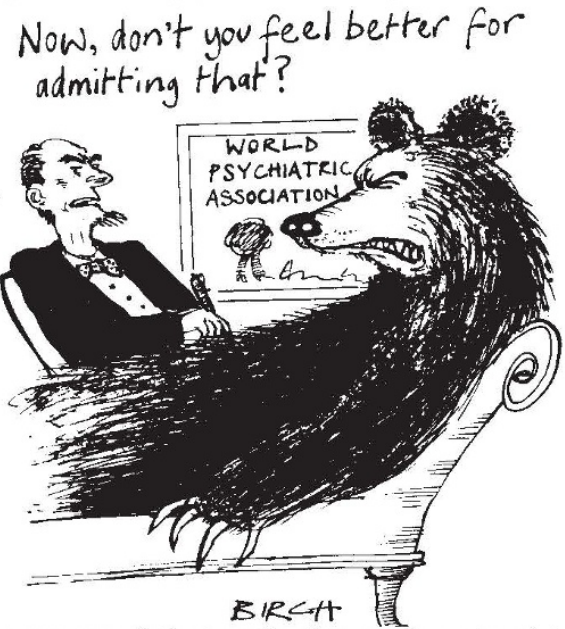

as a proof that such abuses do not exist. An exposure, earlier this year, by the newspaper Sotsialisticheskaya Industriya. of improper conduct by some psychiatrists dealt not with political cases but with bribe-taking by certain psychiatrists, who certified criminals as mentally incompetent so that they could avoid long prison sentences, or providing young men with certificates to avoid military service.

Sotsialisticheskaya Industriya subsequently received details of cases of the hospitalization of people whose only symptom was to have been overly vocal in their criticism of poor working conditions or economic abuses. In a lengthy interview with the paper, Potapov, himself a psychiatrist, was asked to comment on two such "revenge" committals, in one of which the "patient" was hospitalized on the basis of a work-performance report and two statements by people whom the doctor did not even meet, while in the other, a psychiatric ambulance was summoned to the work-place to collect someone who had expressed some apparently well-founded criticisms.

Potapov replied that the existing regulations on committals should make such cases impossible, "but sometimes the instructions are carried out by people who, regrettably, do not always come up to the necessary professional standard" Several cases of "arbitrary" applications of the rules, leading to "violations of human rights and the sustaining of moral traumas" had been substantiated, he said, and it would therefore be "expedient" to revise the rules so as to make such "broad interpretations" impossible.

In a Soviet context, such an admission is extremely significant. In 1983, the Soviet All-Union Society of Psychiatrists and
Neuropathologists withdrew from the World Psychiatric Association, just in time to forestall its expulsion on grounds of psychiatric abuse. Since then, the society has put out discreet feelers about the possibility of readmission, but has been given to understand, equally discreetly, that colleagues abroad would first want to see good evidence that psychiatric methods of repression were no longer in use against dissidents. The standard Soviet rejoinder is that claims of psychiatric abuse in the Soviet Union are unsubstantiated, and are simply a ploy of antiSoviet campaigners abroad.

Potapov's more cautious approach. admitting that there have been certain infringements, including cases of critics of abuses (which is how most "dissidents" began their careers) seems more liable to evoke credibility abroad and be a more effective road to eventual reinstatement.

Vera Rich

\section{Keck telescope}

\section{San Francisco}

Construction of the dome for the world's largest infrared telescope, the 10-m Keck Telescope, on Mauna Kea in Hawaii, will be finished before the winter snowfall. The $\$ 87$-million telescope is being built as a joint project of the Uni-

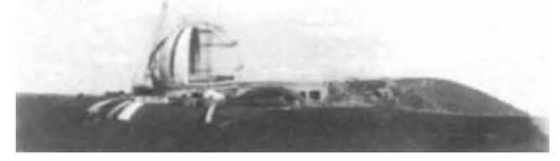

Dome completion soon.

versity of California and the California Institute of Technology.

The telescope will be installed in the autumn of 1988, and assembly and alignment of the telescope's unique honeycomb array of 36 hexagonal mirrors will begin in 1989. The mirror arrangement was conceived as a way to circumvent the distortion and sagging that would necessarily arise because of the weight of a single $10-\mathrm{m}$ mirror.

Two new technologies have been developed for the telescope, a computerized monitoring and adjustment system to keep the mirrors perfectly aligned, and a 'stress mirror polishing' procedure to produce the asymmetrical surface required of each mirror in order to give the final, symmetrical composite surface.

Project spokesman John Gustafson says two mirror segments have been polished so far, but polishing has been halted until final calibration is completed on the device that will test the mirrors for the proper shape. Despite the calibration delays, Gustafson says the project is still on schedule, with plans for the telescope to begin operation in early 1991 .

Marcia Barinaga 